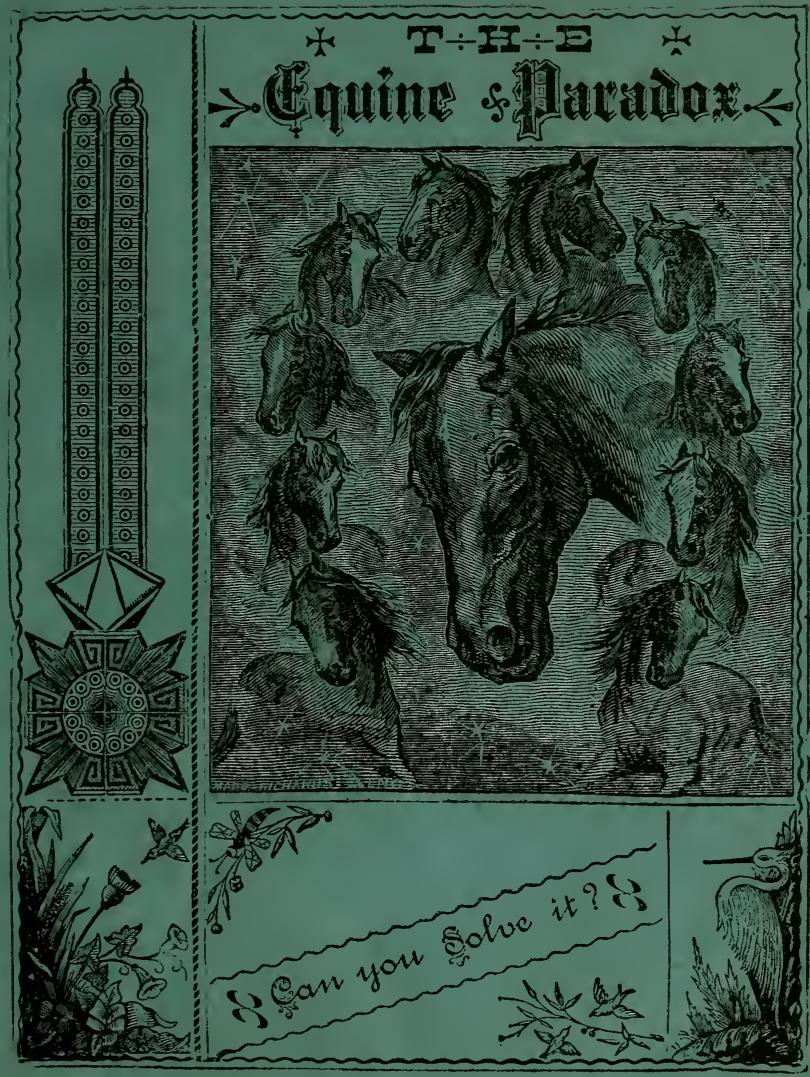


misotydia 5 thace 3 , July 1926

\section{OASC OF OEFRACIHE⿱}

THE PROFESSOR, - - - Geo. BartholomkW A hinight Errant, - $\quad$ - $\quad$ - $\quad$ - Chevalieri A Reasoner, from the Pucer family, - M. Prrscr: The Cnequalled Counterpoise, - - - - - C.Pore 1 Sarage Chief from Louer California, - Mustaxg In -Lssine Judge of the Criminal Court, - - JUD(iE A Whole Constellation, - $\quad-\quad$ - $\quad$ - $\quad$ - Drico The Hambletonirm that takes a hand, - - - Brutrs How can you explain it, - _ _ _ _ - Cxistr Too Lazy for anything, angd no jump, - _ - - JM As Avkward as Comical, - - - - Bucerhales An Arrbirn Maiden, just too cute, - - Miss Neilite A Sprnish Beauty, full of fire, - - - Miss Sprit: The Graceful Daughter of her Sire, MIss ABD.1Lı.MI A Broncho Queen, in love, - - - Mrss BEATTY A Sylph from Fairy Land, - - - Mrss Petrit: The New Pupil, - - - - - - Brack Bili. 


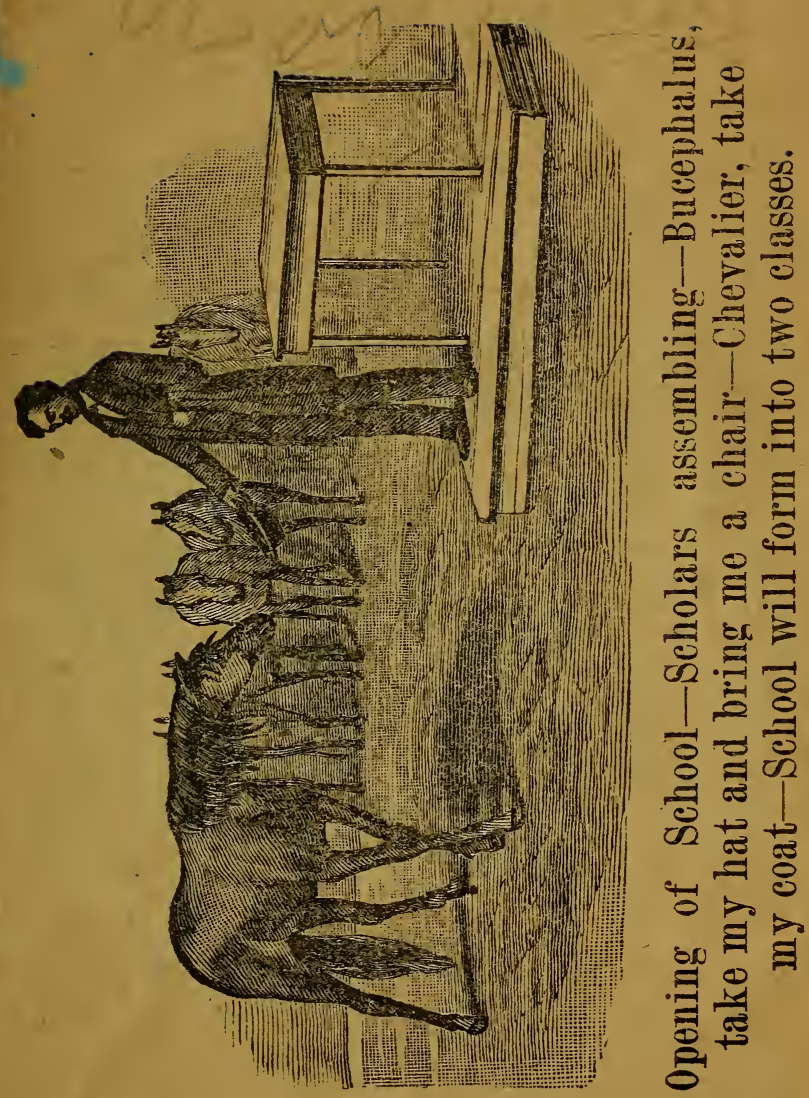




\section{INTRODUCTORY.}

The points deserving special mention, and which we dosire to impress upon the minds of the public that they may the better understand the marked peculiar features so pleasingly presented in the Paradox, are as follows:

The SCHOOL AT PLAY is a work of art, out-vying nature and worthy of studious attention. In this scene, taking from it the laughable and grotesque, is found a most rare and beautiful picture. No herd of wild horses perfectly natural in all their movements, could be more graceful or more artistic in their playful antics. For a troupe of horses to appear on the stage is entirely novel; but for them to be entirely free from all restraining influence under such circumstances is wonderful almost beyond belief.

The LeAP Frog calls out many features of great interest outside of the astonishingly intelligent feats performed. It is unnatural for one horse to jump over another, but it is much more astonishing for the troupe as a whole to insist upon a negligent member doing his part of the performance promptly, plainly proving that they understand the duties of each other as well as their own.

The Military Drill is one of the special features of the exhibition. In it we find the truly wonderful, the marvelous beyond conception. No company of veteran soldiers ever were more perfect in performing intricate evolutions than are the equine enthusiasts of the Professor's school.

The BATtLe Scene lifts the audience to a high pitch of enthusiasm, for in it the school seems filled with inspiration of a high degree. Full of the excitement of what, to them, is a genuine battle, they get wild with frenzy, doing their part with almost electrical rapidity and precision. They are wounded, killed, repulsed, victorious! All joining in the elation of victory over a foe worthy of their steel. 


\section{THHE EQTUINE PHRHDOX. \\ -}

"A paradox! A paradox!

$\triangle$ most enchanting paradox!"

"A school of horses? I never heard of such a thing !" "Turned loose upon the stage? It is extraordinary!"

"Without bridle or rein, obeying every command with the precision of soldiers? Come now, this is too much! I don't believe it!"

And yet it is true. I realize all your doubts, dear reader. It is a wondrous thing, even in this age of wonders, but the reality is more wonderful than your imagination can paint it; much more wonderful! No wizard of old ever claimed to possess such power over the spirits of the air as the wonderful educator of these dumb friends exercises over this school of equines.

They do everything but talk, even doing this in a way all their own-a sort of equine pantomime, fully as expressive as any language could be.

Those who have witnessed their performance many times always find something new, so expressive, so astonishing, that they go away feeling sure that some wizard-like power is possessed by the teacher, enabling him to mesmerize them, if you please, so that they obey his behests.

Let me assure you such is not the case. He is simply their friend, thoroughly understanding their natures, and working upon their powers of perception and understanding, in a way all his own, bringing about results astonishing to you, and yet possible to any student of his peculiar school.

"Was his system a discovery?"

Yes; such a discovery as the student makes who searchea after truth. It was a conclusion, rather than a discovery. Not based upon the laws of evolution, as set down by Darwin, but based upon those sublime truths as set forth in Holy Writ. It took years of patient labor to reach the present results; but failure upon failure only led to more patient study and diligent research, until the laws governing his brute friends were discovered, and success at- 
tained. He found that liorses could be

\section{EDUCATED LIKE CHLDREN,}

to understand and appreciate the value of spoken language as a medium for an intelligent guide to all action, and in 1876 he determined to practically illustrate his theory by putting it to a severe and scientfic test. 'To this end he determined upon selecting a group of horses of different breeds, temperaments, and natural inclinations, that in the group all classes of horses would be represented, proving thereby that, by means of his method of instruction, any naturally intelligent horse could be educated to do not only the will of his master, but by the development of his natural faculties through education, accomplish things hitherto deemed incredible in a brute, indicating, in fact, an ability for reasoning that allied these animals to the human race itself. Animated by this large purpose, he selected fine specinens of the Mustang, the Broncho, and other of the native horses, as well as mixed breeds of noted pedigree, together with the thoroughbrel ARABian NeLlie, that is the peer of any known horse for intelligence, beauty, and erpuine grace. IVith this stud he opened the school which for five years he has so patiently and perseveringly maintained, edncating the horses with a view of presenting his system to the world by giving an exlibit of their intelligence upon the stage, thinking them entirely worthy of being clissed among the most

\section{FINISHED OF ACTOR:}

Audubon, the great ornithologist, went through a sintilar experience, obtaining a never-dying fame as the result of his untiring patience and brilliant genius. Tet his labors belonged to the impracticable scientific, accomplishing good only by increasing our sumeses of knowledge. Professor Bartholomew takes a long step in advance of this, enhancing the value of our must cherished servant by placing him upon an intelligent footing -where he undoubtedly belong - never dreamerl of before.

Why should it ne necessary to pound, to beat, to restrain the horse? He is only too willing to fulfill your wishes. 

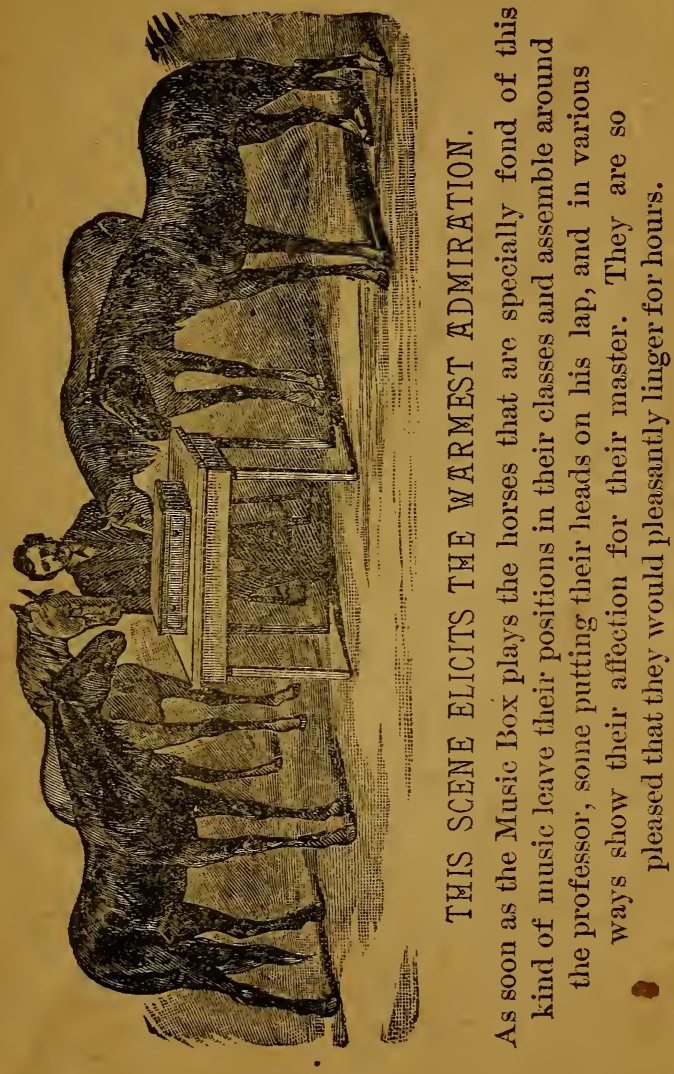
Feed him well, be kind to him, and he will gladly do anything in his power to aid you. Too long has brute humanity out-bruted the brute, not sparing the whip or club to enforce commands willingly obeyed if understood.

\section{If understood?}

In this lies the Professor's success. His pupils are so educated that they understand what is required of them. Line upon line aud precept upoin precept are instilled into their minds, until they are enabled to understand the coinmands of their master intelligentiy.

Why should it be necessary to guide every morement of the horse? It is nor; and the hor'se of the world's tomorrow will simply be told to-

"Take the carriage round to 27 Wisconsin street, then go home to the stable, eat your dinner, and return for me at 5:30, sharp! Yes, and Brutus, tell Cresar to have the groom saddle him so that he can take Willie out riding along the lake shore, say about 2 o'clock."

I do not expect you to believe this possible, for, as yet, you are ignorant of what has been accomplished by this new system of education. You may say, on receiving this little book:

"An advertising dodige! Do they take us for fools?"

We answer you in this wise: This is an advertisement. How else could we make known to you the results attained? But, in addition to this, we emphatically assert that it is a truthful advertisement, stating in the plainest of language, the simple truth. If you believe what is said in this book, you will only believe the truth very modestly stated. Read what is said of us; read what we say of ourselves, and believe it, for it is the truth.

Wo emphatically assert that no language can explain to you the wonderful Paradox that the Equine School ask you to witness and solve.

You cannot help but laugh heartily, and you cannot help but be delighted; you cannot help but be astonished, wonderstruck, amazed, to go away with the desire to come again; to tell all your acquaintances of the wonderful things you have seen, and urge them to go at once and ree the astonishing exhibit. 
Perhaps it would be as well if I were to give a short biographical sketch of Prof. Bartholomew, for it is but natural that general interest should be aroused in regard to a man whose patient endeavor and diligent genius has placed the equine race upon a footing that belong's to it by right of their natural high intelligence:

\section{PROFESSOR GEORGE BARTHOLONEW}

was born May 14th, 1833, in Erie county, N. Y. His father achieved an enviable local reputation as a subduer of fractious animals, and to this bent of his mind was due, no doubt, the life-labor and wonderful achievements of his son, George. Whilst yet a boy the subject of this sketch gave evidence of great power aud marked genius in the handling of all kinds of domestic animals. The most fractious submitted to his will, acknowledging in him a master mind.

So great was his success, even in the benten tracks, that he was led to make the breaking and subduing of horses a life study; and to more fully acquaint himself with all that pertained to his profession, he started, in 1848, for the western plains, where the wild horse roamed in all his native freedom. The termination of his journey found him in San Jose, at the head of San Francisco Bay, full of the gold fever. Two years in the mines cured him of the fever, and gave him means to renew his life-work with greater facilities, filling him with a determination to let naught else distract his mind from his great ambition. Making his home in Oakland, just opposite 'Frisco, he settled down as he thought for life. But great difficulties lay in his war, and ere his discovery of the system that has made him famous was made, many years had come and gone, each with its high and low tides. His life has been most romantic, and its record alone would create such an interest that if we were to give it in this connection, our real object would be lost sight of. Suffice it to say that his perfected scientific system which the Professor very aptly calls PFerde GarTen, was reached only after years of diligent research and active labor, the first fruits of which are now given to the public in this wonderful exhibition It was only after years of patient 


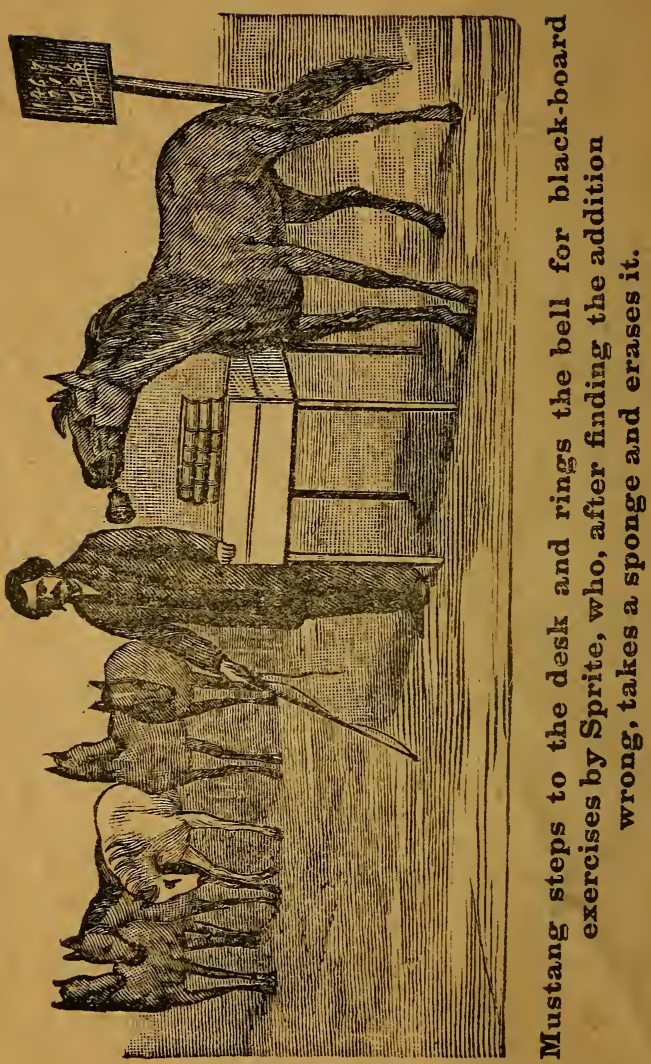




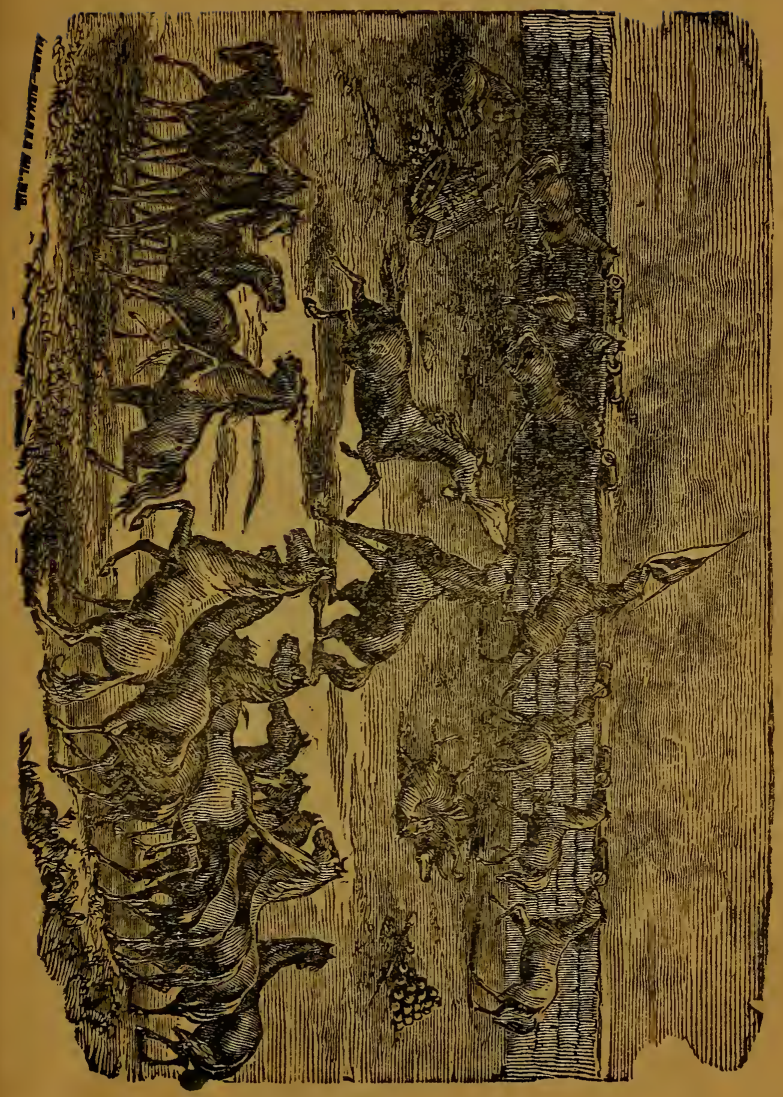

"My men are all dead, Professor, what can I do but surrender?"

"My horses shall take their place." 
The Equine Paradox.

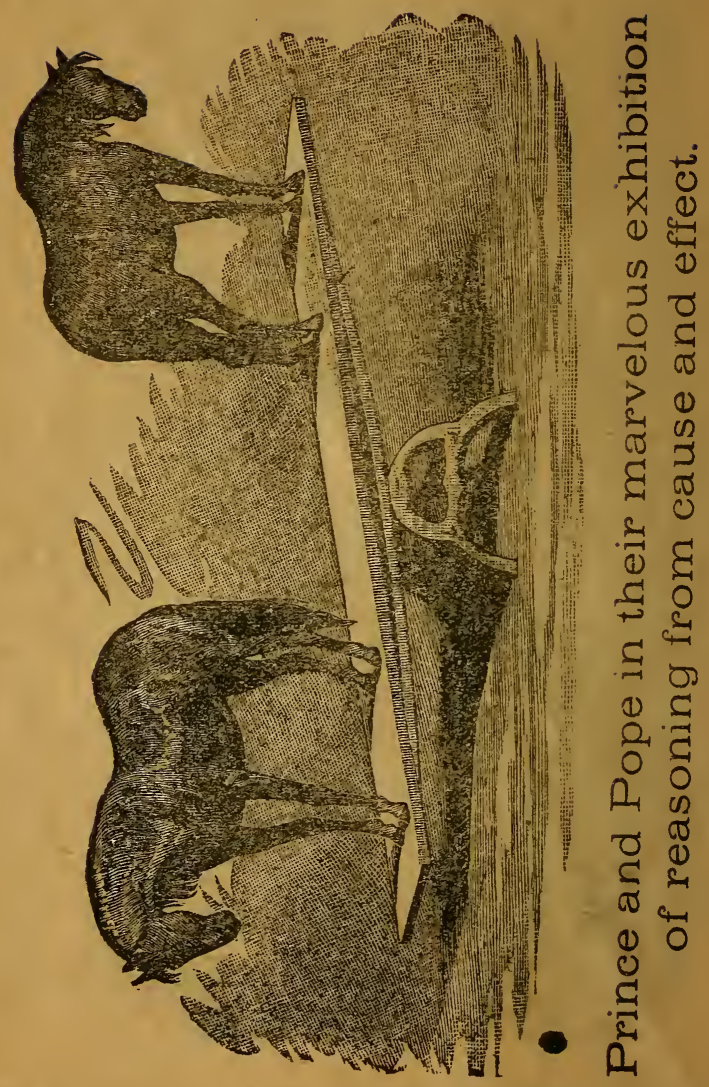




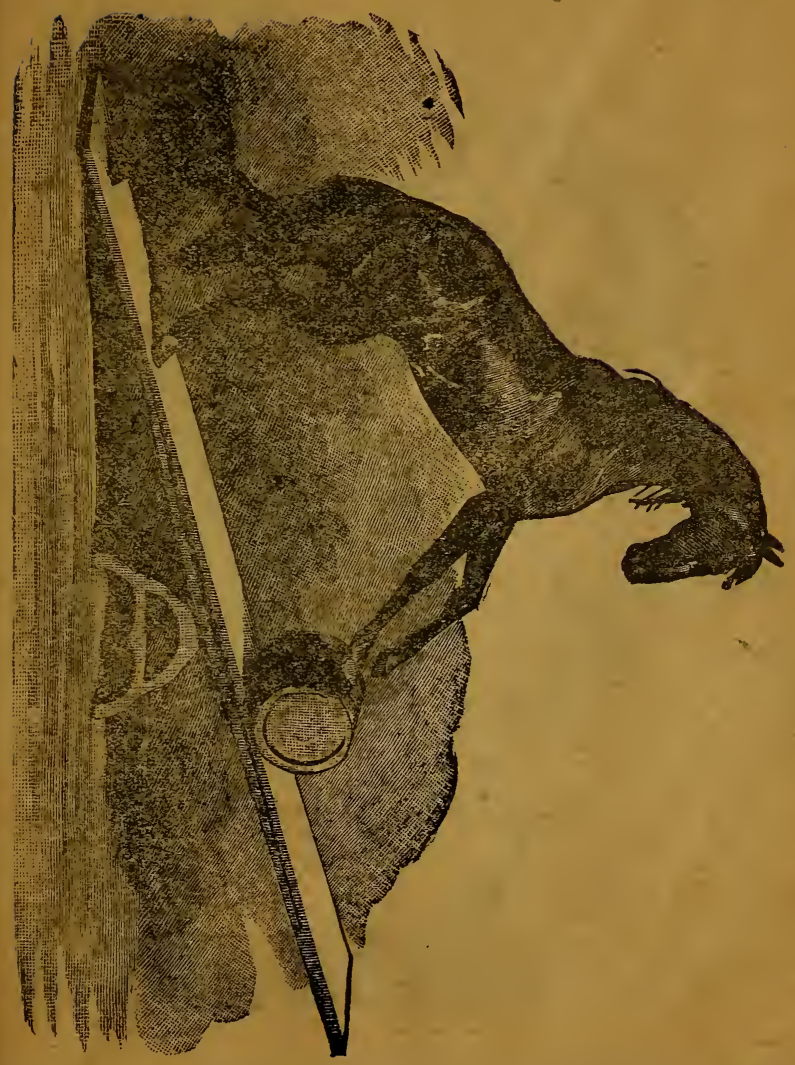

Nellie, in her extraosdinary feat of balanoing with hor fore feot in a barzel, whilo passing oror tho plant. 


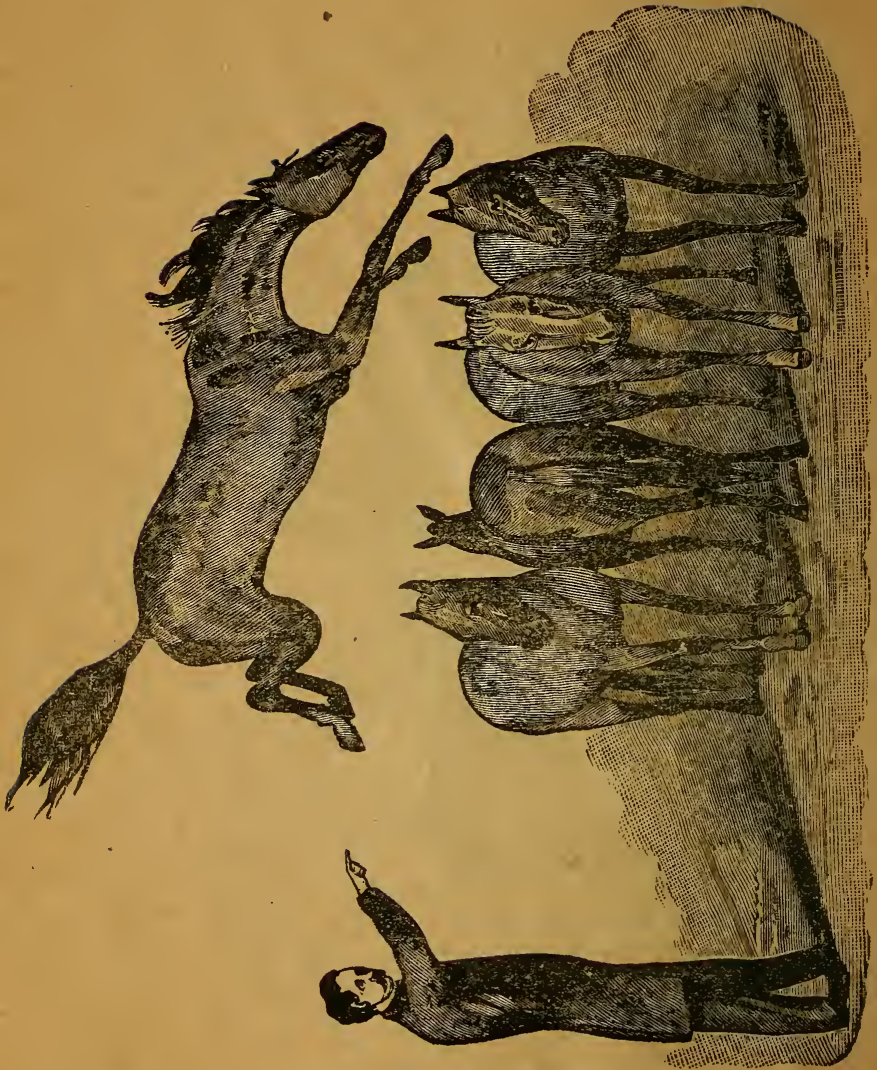

\section{Sprite's unequalled leap on the stage.}


labor and study that he arrived at the conclusion that certain animals, and particular the horse, possessed an intelligence which was subject to development, to a yet unknown degree, and that the severity once deemed essential to secure obedience was like the barbarism practiced upon children of the African tribes, and only served to make more brutish the animals which were ignorantly made to suffer.

As a result of lis life work, we are enabled, to-day, to reach out into the heretofore unknown, and what is yet before us can only be conjectured from what has been accomplished. But let us turn from the Professor to his equine scholars, and give a short description of their peculiarities and pedigrees:-

NELlie is an Arabian mare of great beanty, and possessed of remarkable acuteness. She is a natural flirt, delighting the children and ladies with her pretty ways, and exciting their admiration by her graceful acting. The remark that she is " too cute for anything!" is a very common one, and true to life.

ABDALLAf is Arabian and Messenger, with great symmetry of form and grace of motion. Her beautiful movements and intelligent actions make her a general favorite, though the Professor does not.rank her as high in intelligence as-

CAsAR, a pure Hambletonian. He is very nervous and restless, full of that fire which great mental powers give to man and brute. Some of his acts astonish the most scientific, and set them to considering as to whether the equine race is not fitted for yet greater advancement than the Professor claims for it.

POPE takes the lead in reasoning from cause to effect, proving by his intelligence that the common American carriage horse possesses more good horse-sense than many of their drivers. It is impossible to explain what he does from any other standpoint than that of reasoning from cause and effect, as we do.

Prince steps in and shares equal honors with him, though not so thoroughly reliable, sometimes getting careless and negligently performing his duty. 

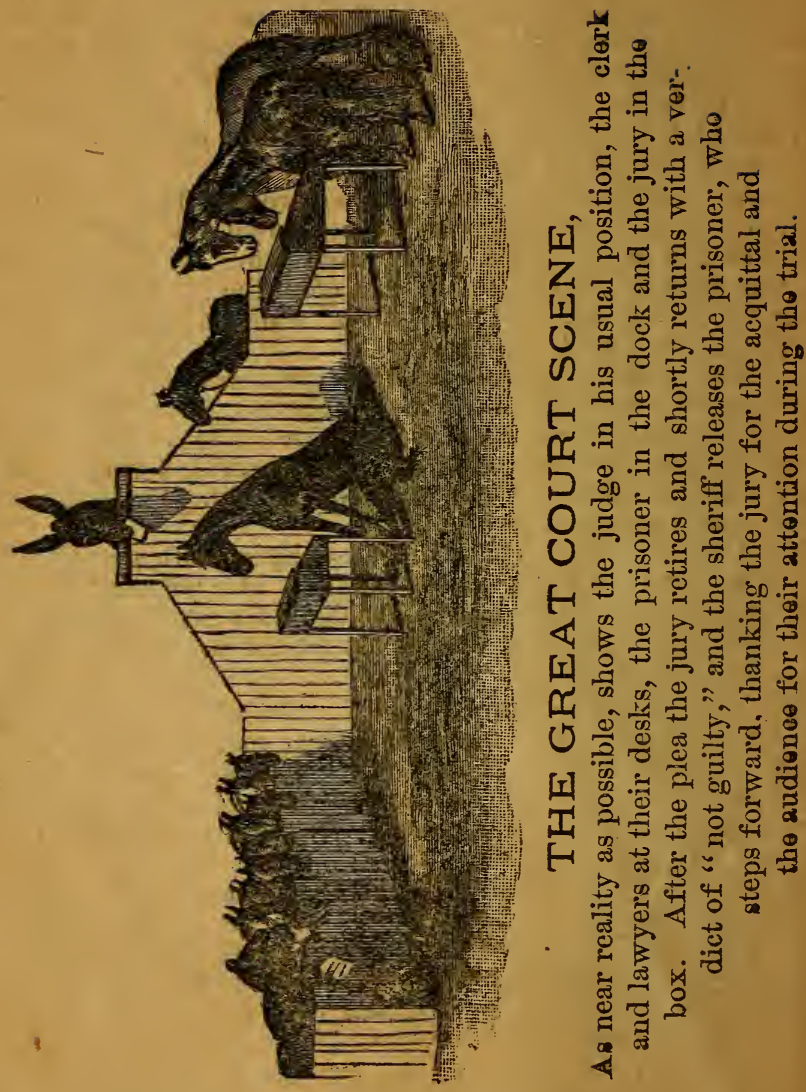
Mustang is the favorita among the boys, for he is full of odd pranks, in keeping with his wild nature. In 1876 he was the leader of a band of wild horses, roaming the broad prairies of New Mexico. Then he was a savage ehief, proud, defiant, and glorying in a seemingly untamable spirit. To-day he is the most obedient of scholars, delighting to exhibit his newly acquired knowledge.

AWKWARD BUCEPHALUS comes next in the list, being a Kentucky thoroughbred of great value, outside of the exhibit. To see him is to laugh, but what he does is well done and always appreciated.

SPRITE AND BEAUTY give evidence of their origin in many ways pleasant to witness, Sprite being a Spanish beauty, and Beauty a Broncho queen. Sprite is worthy of special mention, having merits in harmony with her name. In Leap-Frog she is superb, vying with Mustang for encores.

Chevalier, Draco, Petite, the Judge, and the New PUPIL, BLACK BALL, find their places in the ranks, each adding his mite to make the entertainment pleasant and interesting. Their performance is peculiarly adapted to their different characteristics, making the setting as charming as it is perfect.

BRUTUS AND JrM bring up the rear, but are grand in the Military Drill, where all join in to send you home astonished, wondering if what you have seen is not some vagary of the imagination-a dream that is with you in your waking sense.

\section{THE QUESTION IS,}

Is the Equine race capable of progressive intelligence? As we have known them who could say yes? As we see them in the Professor's school, who dare say, No? Suro it is that they can do everything but talk, and no thinking mind can watch them as they give expression to their remarkable intelligence without saying: "It is incredible, but I am forced to believe what I have seen."

The Humane Society everywhere endorse the Equine Paradox. 

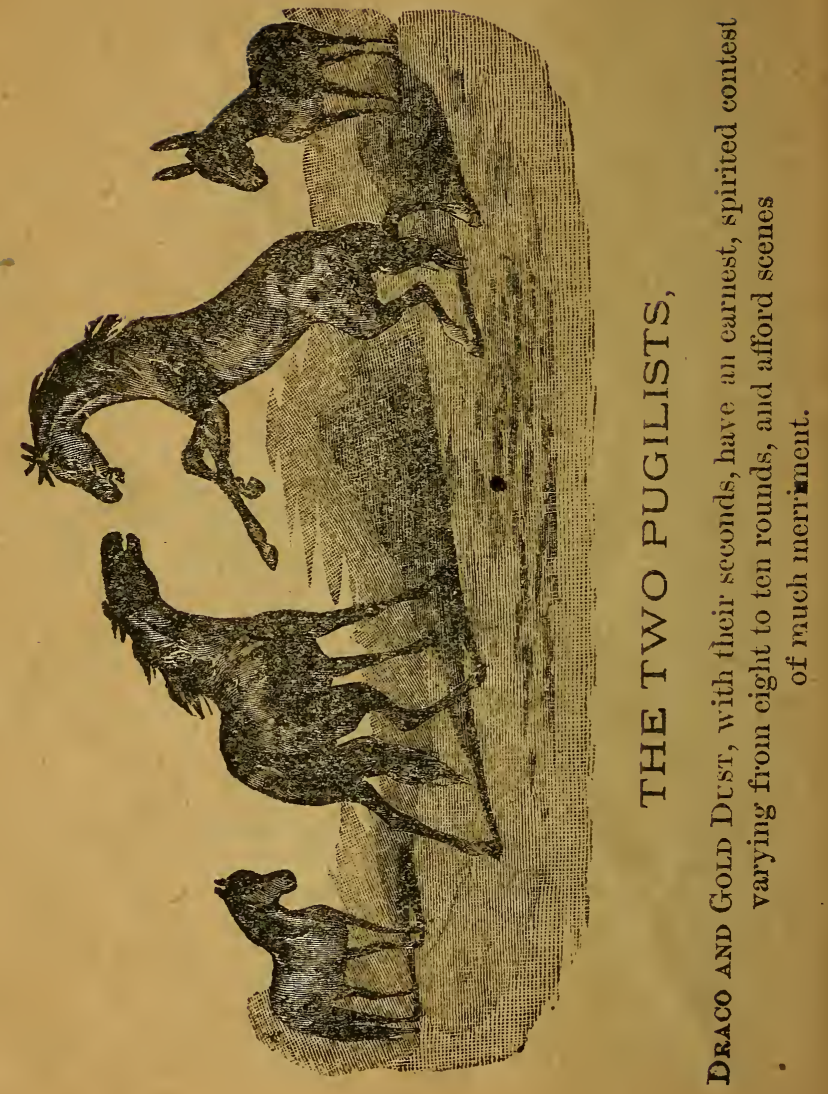


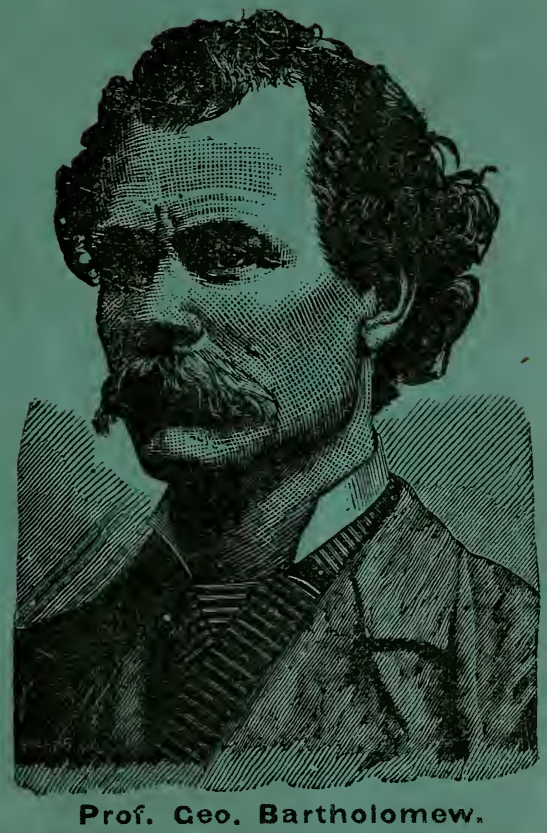




\section{LOW'S OPERA HOUSE,}

\section{PROVIDENCE, R. I.}

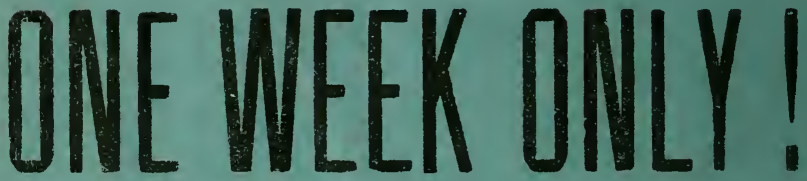

Wednesday and Saturday Matinees!

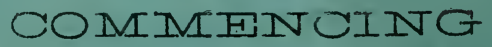

MONDAY, APRIL 16, 1883.

Special Prices, 25, 35, and 50 Cents.

Reserver Seats for all the Entertainments now on Sale at usual places. 